\title{
Digitalisering in de epilepsiezorg
}

Digitalisering speelt een steeds grotere rol in de gezondheidszorg. Dit is een verandering die al lang geleden in gang is gezet, maar vanwege de Covid-r9 pandemie versterkt wordt, zo ook bij epilepsie.

De bijdragen in dit nummer van Epilepsie gaan vooral over zorg op afstand, waarbij het bieden van online zorg een centrale plaats inneemt. Belangrijk in de epilepsiezorg is de controle van aanvallen, bijvoorbeeld hoe vaak en op welke momenten treden aanvallen op en hoe de aanvallen te stoppen. Het is al langer bekend dat de meest gangbare methode voor aanvalsregistratie, het dagboek en/of de aanvalskalender, om allerlei redenen niet betrouwbaar is. Digitalisering van de handmatige registratie is een kleine verbetering, zoals bijvoorbeeld met behulp van My Seizure Diary (http://www.epilepsy.com/get-help/my-epilepsy-diary). Daarnaast zijn er twee op de Nederlandse markt gerichte apps, Helpilepsy en MedApp, die het niet alleen mogelijk maken om aanvallen te registreren, maar ook om dit te combineren met het dagelijks bijhouden van het gebruik van anti-epileptica. De koppeling van een methode voor aanvalsregistratie, bijvoorbeeld via de app Seizure Tracker (http://www.seizuretracker.com) met het elektronische patiëntendossier zou een verbetering van de kwaliteit van aanvalsgegevens opleveren. Ook voor professionals zijn online hulpmiddelen beschikbaar om aanvallen onder controle te houden, zoals de online prediction tool die ondersteuning biedt bij het besluit om te starten of te stoppen met een bepaald anti-epilepticum (www.epilepsypredictiontools.info). Bij het gebruik van de hier genoemde online tools, die mogelijk privacygevoelige gegevens van patiënten verzamelen, dient er echter ook steeds aandacht te blijven voor de ethische en juridische aspecten hiervan.

In dit nummer ook enkele bijdragen over de ontwikkeling van technologie die bedoeld is als ondersteuning bij diagnostiek en behandeling van epilepsie. Bijvoorbeeld door koppeling van aanvalsregistratie aan adequate aanvalsdetectie wordt de registratie van aanvallen objectiever, wat mogelijkheden biedt voor een betere en mogelijk efficiëntere behandeling van mensen met epilepsie. Er is voor patiënten met vooral nachtelijke aanvallen apparatuur beschikbaar voor aanvalsdetectie, zoals de NightWatch (https://nl.nightwatchepilepsy.com) en voor kinderen met absences is er EpiHunter (https://www.epihunter.com). In verschillende bijdragen wordt het voorspellen van aanvallen of van het effect van een medicamenteuze of invasieve behandeling aangestipt, maar de toepassing ervan is nog ver weg. De verwachting is dat voorspellende computermodellen die zijn gebaseerd op artificiële intelligentie hier hoe dan ook een belangrijke rol bij gaan spelen. Implementatie van dergelijke modellen is echter afhankelijk van de beschikbaarheid en toegankelijkheid van de juiste patiëntgebonden en dus privacygevoelige gegevens. Dit is iets om ook nu al rekening mee te houden bij het opzetten van nieuwe onderzoeken.

In een publicatie van Ramadan et al. (https://neurologyopen.bmj.com/content/2/I/eoooo70) is het enorme effect van de Covid-ıg pandemie op de dagelijkse praktijk van de epilepsiezorg van het Henry Ford Hospital (Detroit) beschreven. Op het moment dat de pandemie toesloeg nam het aantal neurofysiologische verrichtingen af tot minder dan Io\% van het totale aantal. Ook werd er vanaf dat moment vrijwel volledig overgeschakeld op videoconsulten of indien gewenst een telefonisch consult (figuur I). Het beeld in Nederland tijdens de lockdown in het begin van dit jaar zal niet zoveel anders zijn geweest. De vraag is hoe de dagelijkse praktijk zich heeft hersteld na afloop van de lockdown en wat de lessen zijn die men heeft geleerd voor de toekomst. Komt er méér aandacht voor bijvoorbeeld EEG-onderzoek in de thuissituatie en wat wordt het beleid rond video-consulten? Een onderwerp dat, zodra de pandemie voorbij is, zeker nader belicht zal worden in 'Epilepsie'.

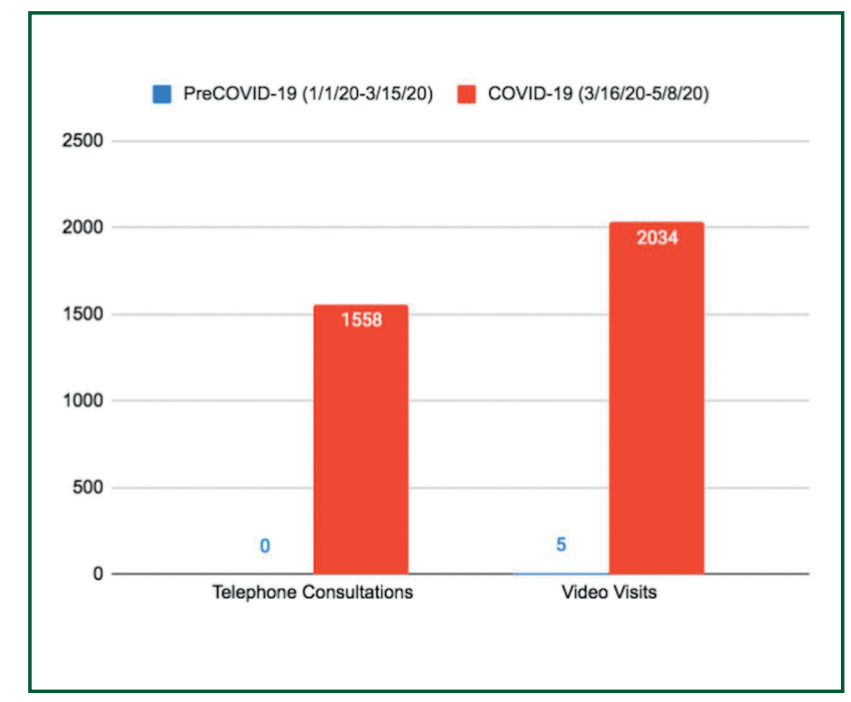

Figurr 1 Het aantal video- en telefonische consulten van de afdeling neurologie van het Henry Ford Hospital in Detroit pre-Covid-19 en gedurende de eerste maand van de Covid-19 pandemie. 